\title{
Ectomycorrhizal fungal communities of silver-fir seedlings regenerating in fir stands and larch forecrops
}

\author{
Rafał Ważny ${ }^{1} \cdot$ Stefan Kowalski $^{2}$
}

Received: 21 June 2016 / Accepted: 23 December 2016 / Published online: 21 January 2017

(C) The Author(s) 2017. This article is published with open access at Springerlink.com

\begin{abstract}
Key message The diversity of ECM communities of 1-year-old silver-fir seedlings regenerating in mature silver-fir stands is significantly higher than in neighboring larch forecrops.

Abstract Forecrop stands provide the necessary shade for shade preferring seedlings, such as silver-fir, which cannot be introduced as the first generation in open areas. Larch is a good candidate, recommended to be utilized as forecrop. Since fungal symbionts of Abies alba seedlings regenerating under larch canopy have not been investigated, we aimed to evaluate the diversity of ECM of 1-year-old silver-fir seedlings regenerating under canopy of larch and to compare these communities to those found in adjacent mature silver-fir stands. Three silver-fir stands $(F)$ and three European larch forecrops $(L)$ were selected to study. Seedling size did not differ between $F$ and $L$ stands. ECM colonization was observed in $100 \%$ silver-fir seedlings in $F$ and $80 \%$ in $L$ stands. The fine roots were highly colonized, and 91 and $87 \%$ of live ECM were found in seedlings from $F$ and $L$ stands, respectively. Sequencing analysis revealed a total 53 ECM taxa. The observed number of ECM taxa in
\end{abstract}

Communicated by P. Courty.

Electronic supplementary material The online version of this article (doi:10.1007/s00468-016-1518-y) contains supplementary material, which is available to authorized users.

Rafał Ważny

rafal.wazny@uj.edu.pl

1 Malopolska Centre of Biotechnology, Jagiellonian University, Gronostajowa 7a, 30-387 Kraków, Poland

2 Department of Forest Pathology, University of Agriculture, 29 Listopada 46, 31-425 Kraków, Poland the $F$ stands was significantly higher (46) than that in the $L$ forecrops (25), and $34 \%$ of taxa were common to both stands. The dominant ECM species in $F$ were unidentified fungus 1, Piloderma sp., Tylospora asterophora and Russula integra. Fir seedlings regenerating in $L$ forecrops formed ectomycorrhizas mostly with unidentified fungus 1 , Tomentella sublilacina, Tylospora sp., Hydnotrya bailii and T. asterophora. Based on ANOSIM analysis, ECM communities have shown significant differences between study sites. The diversity of ECM fungal partners and the high colonization rate of silver-fir seedlings regenerating in larch forecrop stands should be sufficient to provide efficient afforestation of post-arable lands and gives the opportunity for their successful rebuilding.

Keywords Ectomycorrhiza $\cdot$ Abies alba seedlings $\cdot$ Fir stands $\cdot$ Larch forecrops $\cdot$ ITS rDNA

\section{Introduction}

Since the middle of the last century, some of the former arable lands in the Carpathians (Poland) have been afforested with forecrop stands. These stands provide the necessary shade for low light (shade preferring) seedlings, such as Abies alba, which cannot be introduced as the first generation in open areas. Silver-fir is one of the most important forest trees in the mountainous regions of Central Europe (Jaworski 2011). One of the essential environmental factors that determines seed germination (Bormann 1983) and plant growth and subsequently regeneration and survival of silver-fir is the understory light regime. Seedlings and saplings require only 15-25\% of full light (Jaworski 2011), which determine the methods available for regeneration and cultivation during the juvenile stage of the fir beneath 
Table 1 Localization, tree species composition, and soil parameters of the examined silver-fir and larch stands

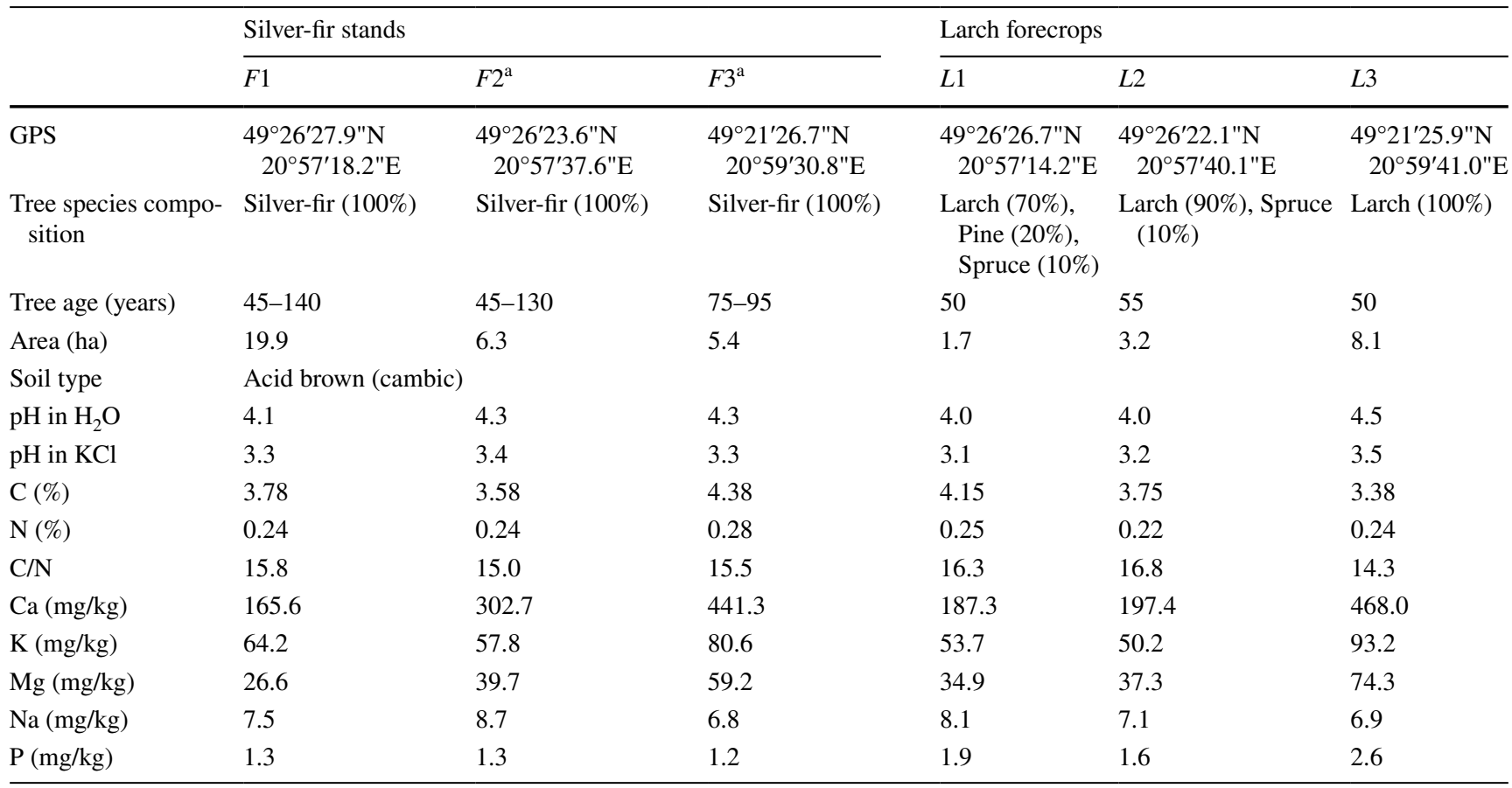

${ }^{a}$ Data published by Ważny $(2011,2014)$

the understory. Among tree species recommended to be utilized as a forecrop, larch is one of the best known candidates due to its ability to provide appropriate light conditions for fir seedlings. It was documented that the optimal conditions for silver-fir seedlings development in the Karkonosze Mountains (Poland) were found under larch canopy (Dobrowolska 2008), demonstrated by the highest increment of height, diameter, and offshoots. Photosynthetically active radiation (PAR) reached $20 \%$ under larch crowns, which positively affected growth of fir needles (Robakowski et al. 2004). Spruce (Picea abies) and beech (Fagus sylvatica) forecrops are unsuitable, because they do not provide recommendable light conditions for fir regeneration (Dobrowolska 2008). Taking into account this aspect larch has become one of the most popular forecrop tree species in the middle of the 20 century for the afforestation of the post-agricultural areas in the Polish Carpathians. Currently, these stands have reached the rebuilding phasemature trees provide habitat for shade preferring silver-fir and these forests are gradually being converted by natural seed regeneration of silver-fir from adjacent stands or planting fir seedlings under the larch canopy. Rebuilding of forecrop stands may take $30-50$ years.

Abies alba is an obligate mutualist with ectomycorrhizal (ECM) fungi (Trappe 1962). Formation of ECM on tree roots protects them against root diseases, ensuring healthy seedling growth (Marx 1969) and increases the survival rate of silverfir seedlings (Kowalski 1982). Studies of ECM communities of silver-fir grown under Scots pine (Pinus sylvestris) canopy documented that the diversity of ECM symbionts was lower in these stands than in mature silver-fir stands (Farfał 2008; Kowalski et al. 1996; Ważny 2014). To our knowledge, the fungal symbionts of $A$. alba seedlings regenerating under larch canopy have not been investigated. Moreover, the mycobionts of A. alba ectomycorrhizas are still poorly identified. The current knowledge of silver-fir symbionts is predominantly based on morphological and anatomical descriptions of ectomycorrhizas (Agerer 1987-2007; Berndt et al. 1990; Comandini et al. 2001; De Román et al. 2005; Dominik 1961; Farfał 2008; Kowalski 1982; Pachlewski 1955; Stępniewska and Rębisz 2004) and fungal fruiting bodies (Laganà et al. 1999, 2002). Only a few molecular investigations of the ECM symbionts that associate with silver-fir have appeared in the literature (Cremer et al. 2009; Eberhardt et al. 2000; Rudawska et al. 2015; Ważny 2014). In our study, we aimed to evaluate the diversity of ECM communities of 1-year-old silver-fir seedlings regenerating under canopy of larch and to compare these communities to those found in adjacent mature silver-fir stands.

\section{Materials and methods}

\section{Study sites}

Six stands located in the Experimental Forestry Unit in Krynica (Poland) were selected for the study: three silver-fir $(A . a l b a)$ stands $(F 1, F 2$, and $F 3)$ and three larch 
(L. decidua) stands $(L 1, L 2$, and $L 3)$ with natural regeneration of silver-fir seedlings. Their detailed description is presented in Table 1. Larch stands were treated as forecrop stands. The paired, $L$ and $F$, stands were neighbored. Each larch forecrop was established on an abandoned area after cultivation. The results from site $F 2$ and $F 3$ were presented in the previous papers by Ważny $(2011,2014)$ and are included here due to the fact that fir stands were used as a reference fir stand for $L 2$ and L3 forecrop stands. For ECM analysis, 30 1-year-old seedlings were sampled along parallel transects spaced 10-20 m apart with minimum intervals of $10 \mathrm{~m}$ between particular seedlings. To avoid edge effect in fir stands, seedlings were collected at least $20 \mathrm{~m}$ from the stand edges. If the seedlings were not abundant in forecrop stands, minimum intervals $(10 \mathrm{~m})$ between samples were omitted. All the seedlings sampled in fir stands were the result of natural regeneration. In the case of larch stands, the number of fir seedlings naturally regenerated was not always enough and sampled seedlings were also the result of artificial regeneration by direct seeding. In forecrops, the places with other tree species were excluded from sample collection. The seedlings were collected together with adjacent soil surrounding the roots (approx. $250 \mathrm{ml}$ ), placed in plastics bags, and stored at $-20^{\circ} \mathrm{C}$ until analysis. In each stand, one bulk soil sample (each being composed of ten subsamples) was collected for chemical analysis.

\section{Seedling parameters}

Average values of a number of mycorrhizal seedlings, number of alive and dead ectomycorrhizas and non-mycorrhizal roots, height and diameter of shoot, and dry weight of shoot and root were assessed.

\section{ECM assessment}

The root system was gently washed in tap water to remove organic and mineral matter. All the root tips per seedling were assessed for mycorrhizal colonization (2520 root tips per 180 seedlings). Ectomycorrhizas were described according to Agerer (1987-2007) based on morphology features (color, shape, and texture of mantle, ectomycorrhiza ramification, presence and appearance of extramatrical hyphae, rhizomorphs, and cistidia). For each morphotype from each site, two-to-six root tips were transferred for molecular identification of the fungal symbiont. DNA extraction was performed according to the modified method by Lanfranco et al. (1998). Amplification of the internal transcribed spacer (ITS) rDNA region was carried out with ITS1F (Gardes and Bruns 1993) and ITS4 (White et al. 1990) primers. The polymerase chain reaction (PCR) was performed as follows: $1 \times$ Pol Buffer; $0.2 \mathrm{mM}$ dNTPs (each); 50 pmol of each primer; and 1 unit Taq DNA polymerase (Eurx). Amplification was carried out as follows: initial denaturation at $93^{\circ} \mathrm{C}$ for $10 \mathrm{~min}$ followed by 35 cycles of 1 -min denaturation at $95^{\circ} \mathrm{C}, 1$-min annealing at $60{ }^{\circ} \mathrm{C}, 2$-min extension at $72^{\circ} \mathrm{C}$, and 10 -min final extension at $72{ }^{\circ} \mathrm{C}$. PCR products were separated by electrophoresis in $1.5 \%$ agarose gel stained with Midori Green. Sequencing was carried out at the Laboratory of Molecular Biology of Adam Mickiewicz University in Poznan, Poland. The ITS4 primer was used for reading sequences. The sequences were edited using BioEdit (Hall 1999) and Chromas (http:// www.technelysium.com.au) software and then compared with published sequences in UNITE (Abarenkov et al. 2010) and NCBI (http://www.ncbi.nlm.nih.gov) databases. A positive identification of a mycorrhizal species was confirmed if they shared $\geq 98 \%$ ITS region sequence identity with the most similar (reference) sequence from UNITE or NCBI databases. The obtained sequences within $2 \%$

Table 2 Biometric parameters and mycorrhizal colonization of Abies alba seedlings regenerating in fir stands $(F)$ and larch forecrops $(L)$

\begin{tabular}{|c|c|c|c|c|c|c|c|c|}
\hline Parameters & $F 1$ & $F 2^{\mathrm{a}}$ & $F 3^{\mathrm{a}}$ & $L 1$ & $L 2$ & $L 3$ & $F^{\mathrm{b}}$ & $L^{\mathrm{b}}$ \\
\hline Height $(\mathrm{cm})$ & $4.8 \pm 0.1$ & $4.8 \pm 0.1$ & $5.1 \pm 0.1$ & $4.8 \pm 0.1$ & $4.9 \pm 0.1$ & $4.2 \pm 0.1$ & $4.9 \pm 0.1 \mathrm{a}$ & $4.6 \pm 0.2 \mathrm{a}$ \\
\hline Diameter (mm) & $0.9 \pm 0.0$ & $1.0 \pm 0.0$ & $1.0 \pm 0.0$ & $0.9 \pm 0.0$ & $0.9 \pm 0.0$ & $1.0 \pm 0.0$ & $1.0 \pm 0.0 \mathrm{a}$ & $0.9 \pm 0.0 \mathrm{a}$ \\
\hline Dry weight (g) & $0.028 \pm 0.003$ & $0.034 \pm 0.003$ & $0.040 \pm 0.003$ & $0.025 \pm 0.003$ & $0.026 \pm 0.003$ & $0.030 \pm 0.003$ & $0.033 \pm 0.003 \mathrm{a}$ & $0.027 \pm 0.001 \mathrm{a}$ \\
\hline $\begin{array}{l}\text { Mycorrhizal seed- } \\
\text { lings (\%) }\end{array}$ & 100.0 & 100.0 & 100.0 & 80.0 & 70.0 & 90.0 & $100.0 \pm 0.0 \mathrm{~b}$ & $80.0 \pm 5.8 \mathrm{a}$ \\
\hline $\begin{array}{l}\text { Live mycorrhizas } \\
\quad(\%)\end{array}$ & 87.3 & 86.4 & 100.0 & 96.5 & 68.5 & 96.1 & $91.2 \pm 4.4 \mathrm{a}$ & $87.0 \pm 9.3 \mathrm{a}$ \\
\hline $\begin{array}{l}\text { Non-mycorrhizal } \\
\text { roots }(\%)\end{array}$ & 12.7 & 13.6 & 0.0 & 2.8 & 30.6 & 3.9 & $8.8 \pm 4.4 \mathrm{a}$ & $12.5 \pm 9.1 \mathrm{a}$ \\
\hline $\begin{array}{l}\text { Dead mycorrhizas } \\
(\%)\end{array}$ & 0.0 & 0.0 & 0.0 & 0.7 & 0.9 & 0.0 & $0.0 \pm 0.0 \mathrm{a}$ & $0.5 \pm 0.3 \mathrm{a}$ \\
\hline
\end{tabular}

${ }^{\text {a } D a t a ~ p u b l i s h e d ~ b y ~ W a z ̇ n y ~}(2011,2014)$; different letters between $F$ and $L$ mean statistically significant differences $(t$ test, $p \leq 0.05)$

${ }^{\mathrm{b}}$ Data are presented as a mean $\pm \mathrm{SE}(n=3)$ 
Table 3 Relative abundance (RA) and frequency (FR) of ectomycorrhizal taxa on the roots of 1-year-old Abies alba seedlings regenerating in fir stands $(F 1, F 2$, and $F 3)$ and larch forecrops $(L 1, L 2$, and $L 3)$

\begin{tabular}{|c|c|c|c|c|c|c|c|c|c|c|c|c|}
\hline \multirow[t]{2}{*}{ Fungal species } & \multicolumn{2}{|l|}{$F 1$} & \multicolumn{2}{|l|}{$F 2^{\mathrm{a}}$} & \multicolumn{2}{|l|}{$F 3^{\mathrm{a}}$} & \multicolumn{2}{|l|}{$L 1$} & \multicolumn{2}{|l|}{$L 2$} & \multicolumn{2}{|l|}{$L 3$} \\
\hline & $\mathrm{RA}$ & FR & $\mathrm{RA}$ & FR & $\mathrm{RA}$ & FR & $\mathrm{RA}$ & FR & $\mathrm{RA}$ & FR & $\mathrm{RA}$ & FR \\
\hline Amanita muscaria & & & & & 1.6 & 13.3 & & & & & & \\
\hline Amanita rubescens & 3.3 & 3.3 & & & & & & & & & & \\
\hline Boletus edulis & & & & & 0.7 & 6.7 & & & & & & \\
\hline Boletus pruinatus & 0.5 & 6.7 & 2.0 & 6.7 & 3.9 & 13.3 & 1.3 & 6.7 & & & & \\
\hline Cenococcum geophilum & 1.9 & 10.0 & 5.6 & 13.3 & 2.7 & 16.7 & & & & & 0.3 & 3.3 \\
\hline Clavulina cristata & 11.8 & 23.3 & & & & & & & & & & \\
\hline Clavulina sp. 1 & & & 5.3 & 23.3 & 1.4 & 10.0 & & & & & 12.0 & 6.7 \\
\hline Cortinarius sp. 1 & & & & & 0.5 & 10 & & & & & & \\
\hline Cortinarius sp. 2 & 5.8 & 6.7 & & & & & & & & & & \\
\hline Cortinarius sp. 3 & & & & & 1.4 & 10 & & & & & & \\
\hline Elaphomyces muricatus & 1.4 & 3.3 & & & 2.1 & 6.7 & & & 0.7 & 3.3 & & \\
\hline Entoloma sp. & 1.4 & 3.3 & & & & & & & & & & \\
\hline Hydnotrya bailii & & & & & & & 23.1 & 20.0 & & & & \\
\hline Hydnotrya sp. & & & & & 2.8 & 6.7 & & & & & & \\
\hline Hydnotrya tulasnei & & & & & & & & & 2.9 & 10.0 & & \\
\hline Hydnum rufescens & & & & & 2.3 & 3.3 & & & & & & \\
\hline Laccaria laccata & & & & & & & & & & & 7.7 & 13.3 \\
\hline Laccaria maritima & & & & & & & & & 1.4 & 3.3 & & \\
\hline Lactarius aurantiacus & & & & & 8.2 & 30.0 & & & & & & \\
\hline Lactarius lignyotus & 1.1 & 3.3 & & & & & & & & & & \\
\hline Lactarius necator & & & & & & & & & 13.4 & 23.3 & & \\
\hline Leotiomycetes & & & & & 6.2 & 13.3 & & & & & & \\
\hline Mycena galopus & & & & & & & 2.0 & 3.3 & & & & \\
\hline Paxillus involutus & & & & & 1.1 & 3.3 & & & & & & \\
\hline Piloderma cf. byssinum & & & & & 0.9 & 3.3 & & & & & & \\
\hline Piloderma fallax & 0.3 & 3.3 & & & 2.5 & 13.3 & & & & & & \\
\hline Piloderma sp. 1 & & & 32.2 & 20.0 & & & & & & & & \\
\hline Pseudotomentella sp. 1 & & & 5.1 & 20.0 & & & 1.6 & 6.7 & & & & \\
\hline Pseudotomentella sp. 2 & 7.7 & 6.7 & & & & & & & 2.2 & 3.3 & & \\
\hline Russula amethystina & 7.1 & 6.7 & & & 4.8 & 20.0 & & & & & & \\
\hline Russula cyanoxantha & & & 1.0 & 6.7 & & & & & & & & \\
\hline Russula fellea & 2.5 & 3.3 & & & & & & & & & & \\
\hline Russula integra & 18.1 & 26.7 & 11.1 & 20.0 & & & & & & & 4.3 & 6.7 \\
\hline Russula ochroleuca & & & & & & & & & 15.2 & 20.0 & & \\
\hline Russula olivacea & & & 1.0 & 3.3 & 5.7 & 23.3 & & & & & & \\
\hline Russula puellaris & & & 0.8 & 3.3 & & & 5.2 & 6.7 & & & & \\
\hline Russula sp. 1 & 6.9 & 6.7 & 0.3 & 3.3 & & & & & & & & \\
\hline Russula vesca & 0.8 & 3.3 & & & & & & & & & & \\
\hline Sebacina sp. 1 & 0.8 & 3.3 & & & & & & & 3.6 & 3.3 & & \\
\hline Sebacina sp. 2 & & & & & 0.7 & 3.3 & & & & & & \\
\hline Sebacina sp. 3 & 12.1 & 26.7 & & & & & & & 2.9 & 6.7 & & \\
\hline Thelephora sp. & 1.1 & 6.7 & & & & & & & & & 5.4 & 6.7 \\
\hline Thelephora terrestris & & & 1.3 & 3.3 & & & 2.9 & 6.7 & & & & \\
\hline Tomentella stuposa & & & & & 7.3 & 30.0 & & & & & & \\
\hline Tomentella sublilacina & & & 2.5 & 3.3 & & & & & & & 45.6 & 56.7 \\
\hline Tomentellopsis sp. & 0.5 & 6.7 & 0.5 & 3.3 & & & & & & & & \\
\hline Tylospora asterophora & 11.8 & 40 & 8.1 & 20.0 & 6.8 & 16.7 & & & & & 17.8 & 30.0 \\
\hline Tylospora fibrillosa & & & 4.6 & 10.0 & & & 5.9 & 13.3 & & & & \\
\hline Tylospora sp. & & & 3.0 & 10.0 & & & 20.2 & 26.7 & 23.9 & 30.0 & & \\
\hline
\end{tabular}


Table 3 (continued)

\begin{tabular}{|c|c|c|c|c|c|c|c|c|c|c|c|c|}
\hline \multirow[t]{2}{*}{ Fungal species } & \multicolumn{2}{|l|}{$F 1$} & \multicolumn{2}{|l|}{$F 2^{\mathrm{a}}$} & \multicolumn{2}{|l|}{$F 3^{\mathrm{a}}$} & \multicolumn{2}{|l|}{$L 1$} & \multicolumn{2}{|l|}{$L 2$} & \multicolumn{2}{|l|}{$L 3$} \\
\hline & RA & FR & $\mathrm{RA}$ & FR & RA & FR & $\mathrm{RA}$ & FR & RA & FR & RA & FR \\
\hline Unidentified 1 & & & 13.4 & 13.3 & 35.1 & 70.0 & 37.8 & 53.3 & 33.0 & 33.3 & 6.9 & 16.7 \\
\hline Unidentified 2 & & & 2.3 & 6.7 & & & & & & & & \\
\hline Unidentified 3 & 1.9 & 3.3 & & & & & & & & & & \\
\hline Xerocomus badius & 1.1 & 3.3 & & & 1.1 & 3.3 & & & 0.7 & 3.3 & & \\
\hline
\end{tabular}

${ }^{\mathrm{a}}$ Data published by Ważny $(2011,2014)$

nucleotide difference were categorized as a single operational unit and assigned an identical name.

\section{Soil assessment}

The $\mathrm{pH}$ was determined in $\mathrm{H}_{2} \mathrm{O}$ and $\mathrm{KCl}$, the $\mathrm{C}$ content was analyzed by the Tiurin method, and the $\mathrm{N}$ content by the Kjeldahl method and the macronutrient $(\mathrm{Ca}, \mathrm{K}, \mathrm{Mg}, \mathrm{Na})$ content in the soil was determined in $1 \mathrm{M} \mathrm{CH}_{3} \mathrm{COONH}_{4}$ with the ICP-OES Thermo iCAP 6500 DUO spectrophotometer (Ostrowska et al. 1991).

\section{Data analysis}

Statistical analysis of the seedling biometric data (height, diameter and dry weight) was performed with the parametric $t$ test and nonparametric Mann-Whitney $U$ test using Statistica 10.0 (StatSoft 2011) at the level of significance $\alpha=0.05$. The nonparametric test was used when Shapiro-Wilk normality and Levene's homogeneity of variance were not found. To assess if a sufficient number of samples were collected, the observed species accumulation curve and jackknife first-degree estimator curve with 100 randomization with sample replacement were plotted in the Estimates 9.1.0 software (Colwell 2006). Communities of ECM fungi were described by species richness (number of identified mycorrhizal taxa), relative abundance (number of mycorrhizas of a given mycorrhizal species per total number of mycorrhizas in each site), and frequency (ratio of number of seedlings with given ECM taxa to total number of seedlings in each stand). The ECM species diversity was evaluated by Shannon-Wiener's $\left(H^{\prime}\right)$ and Simpson's $(1 D)$ indicators. The variability of ECM composition among seedlings of different forest stands was visualized using non-metric multidimensional scaling (NMDS). Analysis of similarity ANOSIM was used to determine if relative abundance of ECM symbionts differed between study sites. The above coefficients, ANOSIM, NMDS, and the cluster analysis were calculated in PAST 2.17 software (Hammer et al. 2001) based on standardized, square root transformed data of each taxa. The Bray-Curtis dissimilarity coefficient was chosen for calculation in analyses (Bray and Curtis 1957).

\section{Results}

ECM colonization was observed in $100 \%$ silver-fir seedlings in $F$ and was significantly higher than in $L$ stands (80\%). The fine roots were highly colonized, 91 and $87 \%$ of live ECM were found in seedlings from $F$ and $L$ stands, respectively (Table 2).

Sequencing analysis revealed a total 53 ECM taxa on silver-fir seedlings (Table 3). The observed number of ECM taxa in the $F$ stands was significantly higher than that in the $L$ forecrops; 46 taxa were present on seedlings in $F$ stands and 25 taxa were present on seedlings in $L$ stands (Fig. 1). Based on the jackknife first-degree estimator, the observed number of taxa was $77 \%$ of the estimated richness in fir stands and $78 \%$ of the estimated number of ECM species in larch forecrops (Fig. 2). Thirty-three ECM morphotypes were described to the species level. Three morphotypes were unidentified to any taxa. Eighteen out of 53 taxa (34\%) were common to both stands. The dominant ECM species identified in seedlings regenerating in fir stands were: unidentified fungus 1 (18.9\%), followed by Piloderma sp. (9.6\%), Tylospora asterophora (8.6\%) and Russula integra (8.3\%). Fir seedlings regenerating under larch canopy formed ectomycorrhizas mostly with unidentified fungus 1 (24.8\%), Tomentella sublilacina (17.1\%), Tylospora sp. (13.7\%), Hydnotrya bailii (7.6\%), and T. asterophora (6.7\%) (Fig. 1).

Species richness per site was twofold higher in studied $F$ stands (18-22) compared to $L$ stands (8-11) (Table 3 ). Similarly, species richness per one seedling was also higher in $F$ stands (1.9-3.3 versus 1.4). The Shannon-Wiener and Simpson's indices for the ECM assemblages were higher in $F$ stands $(2.28-2.58$ and $0.85-0.90)$ than in $L$ stands (1.61-1.81 and 0.73-0.79), respectively (Table 4).

Based on ANOSIM analysis, ECM communities have shown significant differences $(R=0.2771, p=0.0001)$ between study sites. Non-metric multidimensional scaling plot grouped $L 1, L 2$, and $F 3$ sites closely (Fig. 3). This observation was confirmed in the similarity dendrogram for the ECM fungi assemblages in study sites (Fig. 4). Here, the most similar (66\%) ECM communities were found in $L 1$ and $L 2$ stands. Closely related to this clade was ECM communities noted in $F 3$ stand. 
Fig. 1 Mean relative abundance of ECM fungi on 1-year-old Abies alba seedlings regenerating in fir stands and larch forecrops
Laccaria maritima
Mycena galopus

Hydnotrya tulasnei

Laccaria laccata

Lactarius necator

Russula ochroleuca

Hydnotrya bailii

Russula vesca

Cortinarius sp. 1

Sebacina sp. 1

Russula puellaris

Tomentellopsis sp.

Sebacina sp. 2

Russula cyanoxantha

Lactarius lignyotus

Boletus edulis

Thelephora sp.

Piloderma cf. byssinum Entoloma sp.

Thelephora terrestris

Paxillus involutus

Unidentified 3

Cortinarius sp. 3

Unidentified 2

Russula fellea

Amanita muscaria

Xerocomus badius

Tomentella sublilacina

Amanita rubescens

Tylospora sp.

Hydnum rufescens

Piloderma fallax

Hydnotrya sp.

Elaphomyces muricatus

Tylospora fibrillosa

Pseudotomentella sp. 1

Cortinarius sp. 2

Russula sp.

Pseudotomentella sp. 2

Clavulina sp. 1

Boletus pruinatus

Leotiomycetes

Russula olivacea

Tomentella stuposa

Clavulina cristata

Cenococcum geophilum

Sebacina sp. 3

Lactarius aurantiacus

Russula amethystina

Russula integra

Tylospora asterophora

Piloderma sp.

Unidentified 1

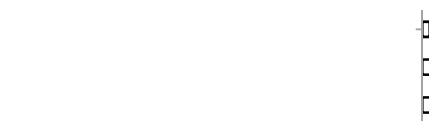

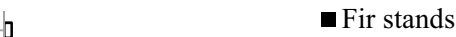

口Larch forecrops

$\square$
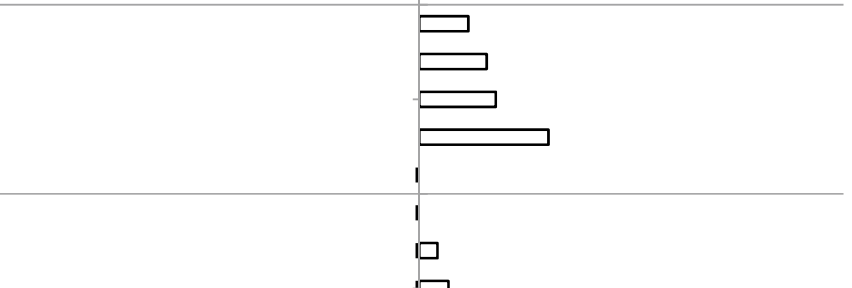

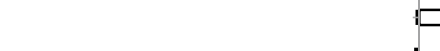

I

I

,

回

I

I

:

I

-

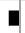

-

E

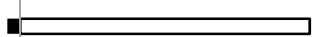

-

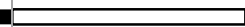

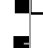

-

-

-

-

$=0$

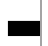

0

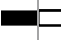

$=0$

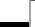

$\square$

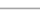

$\square$

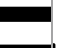

$\Rightarrow$

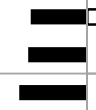

$\square$
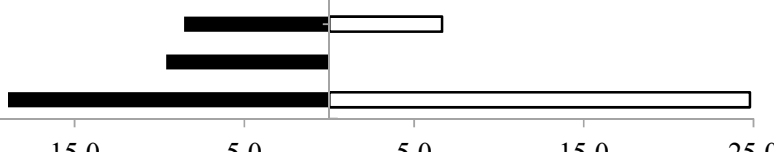

5.0

5.0

15.0

25.0

Relative abundance [\%] 

richness estimation curves for 1-year-old Abies alba seedlings regenerating in fir $(F)$ and larch $(L)$ stands. Sobs-species observed, Jack1-first order jackknife estimator (100 randomized runs with sample replacement were used)
Fig. 2 Ectomycorrhizal species

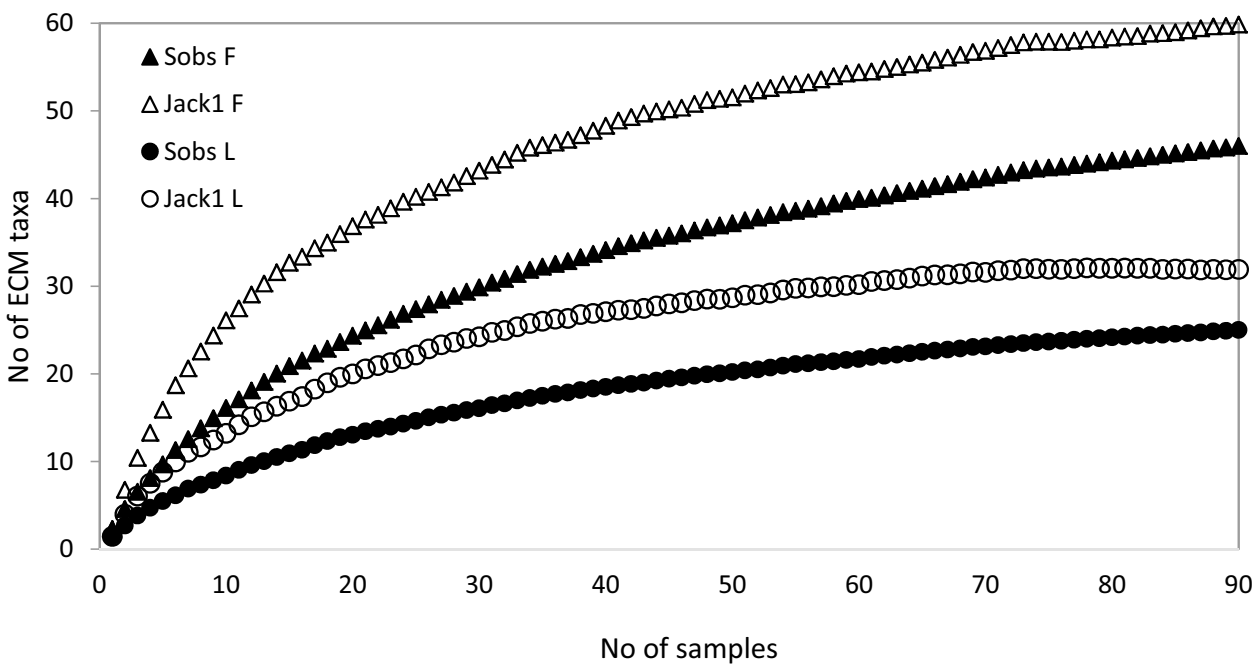

Table 4 Diversity indices of ECM communities colonizing Abies alba seedlings regenerating in fir stands $(F)$ and larch forecrops $(L)$

\begin{tabular}{lllllllll}
\hline Parameters & $F 1$ & $F 2^{\mathrm{a}}$ & $F 3^{\mathrm{a}}$ & $L 1$ & $L 2$ & $L 3$ & $F^{\mathrm{b}}$ & $L^{\mathrm{b}}$ \\
\hline Richness per site & 22 & 18 & 22 & 9 & 11 & 8 & $20.7 \pm 1.3 \mathrm{~b}$ (total 46) & $9.3 \pm 0.9 \mathrm{a}$ (total 25) \\
Richness per seedlings & 2.1 & 1.9 & 3.3 & 1.4 & 1.4 & 1.4 & $2.4 \pm 0.4 \mathrm{a}$ & $1.4 \pm 0.0 \mathrm{a}$ \\
Shannon-Wiener $\left(H^{\prime}\right)$ & 2.58 & 2.28 & 2.44 & 1.65 & 1.81 & 1.61 & $2.43 \pm 0.09 \mathrm{~b}$ & $1.69 \pm 0.06 \mathrm{a}$ \\
Simpson $(1-D)$ & 0.90 & 0.85 & 0.85 & 0.76 & 0.79 & 0.73 & $0.87 \pm 0.02 \mathrm{~b}$ & $0.76 \pm 0.02 \mathrm{a}$ \\
Dominance $(D)$ & 0.10 & 0.15 & 0.15 & 0.24 & 0.21 & 0.27 & $0.13 \pm 0.02 \mathrm{~b}$ & $0.24 \pm 0.02 \mathrm{a}$ \\
\hline
\end{tabular}

${ }^{\text {a }}$ Data published by Ważny $(2011,2014)$; different letters between $F$ and $L$ mean statistically significant differences ( $t$ test, $p \leq 0.05$ )

${ }^{\mathrm{b}}$ Data are presented as a mean $\pm \mathrm{SE}(n=3)$
Soil parameters are presented in Table 1. The $\mathrm{pH}$ value was similar among study sites, ranging from 4.0 to 4.5 in $\mathrm{H}_{2} \mathrm{O}$ and from 3.1 to 3.5 in $\mathrm{KCl}, \mathrm{C} / \mathrm{N}$ ratio ranged from 14.3 to $16.8 \%$. Content of $\mathrm{K}$ ranged from 1.2 to 1.3 in $F$ sites to $1.6-2.6 \mathrm{mg} / \mathrm{kg}$ in $L$ sites.

Biometric parameters (height, diameter, and dry weight) of the seedlings did not differ between fir $(F)$ and larch $(L)$ stands (Table 2). However, in the sites with the lowest percentage of mycorrhizal seedlings ( $L 1$ and $L 2$ ), diameter and dry weight of the seedlings were significantly higher in mycorrhizal seedlings compared to non-mycorrhizal seedlings (data not published).

\section{Discussion}

To our knowledge, this is the first report concerning ECM of 1-year-old A. alba seedlings regenerating in larch forecrops using molecular approaches. Our study has shown that the diversity of ECM communities of 1-year-old silverfir seedlings regenerating in larch forecrops is lower than in neighboring mature silver-fir stands. This result supports our previous observation documented in Scots pine forecrops (Ważny 2014). Species richness, Shannon-Wiener and Simpson's diversity indices were significantly higher in mature fir stands compared to forecrops. Fungal colonization of fine roots in both stands ( $F$ and $L$ ) was very high (91 and $87 \%$, respectively). Species richness in larch forecrops (8-11) was similar to the one reported in Scots pine forecrops (7-12) (Ważny 2014).

Only $34 \%$ fungal symbionts of silver-fir seedlings were common to fir and larch stands. The vast majority (66\%) of fungal symbiont of silver-fir seedlings in larch forecrops were not common with silver-fir in fir stands and may be shared with coexisting mature European larch. For instance, Abies homolepis, closely related to A. alba, grown in broadleaf forest initially shared ECM with broadleaf trees and become colonized be specific ECM many years after its establishment (Ishida et al. 2007). Similarly, as it was suggested by Rudawska et al. (2015), tree species grown outside its range are readily colonized by available and compatible ECM fungi. CMN is likely to be the dominant form of infection for regenerating seedlings (Nara 2008).

In this study, we identified 53 ECM taxa [sampling intensity $(\mathrm{SI})=180$ samples]. A similar ECM morphotype richness (48) was found on mature silver-fir trees in Apennines (Italy) by Comandini et al. (2001). On 


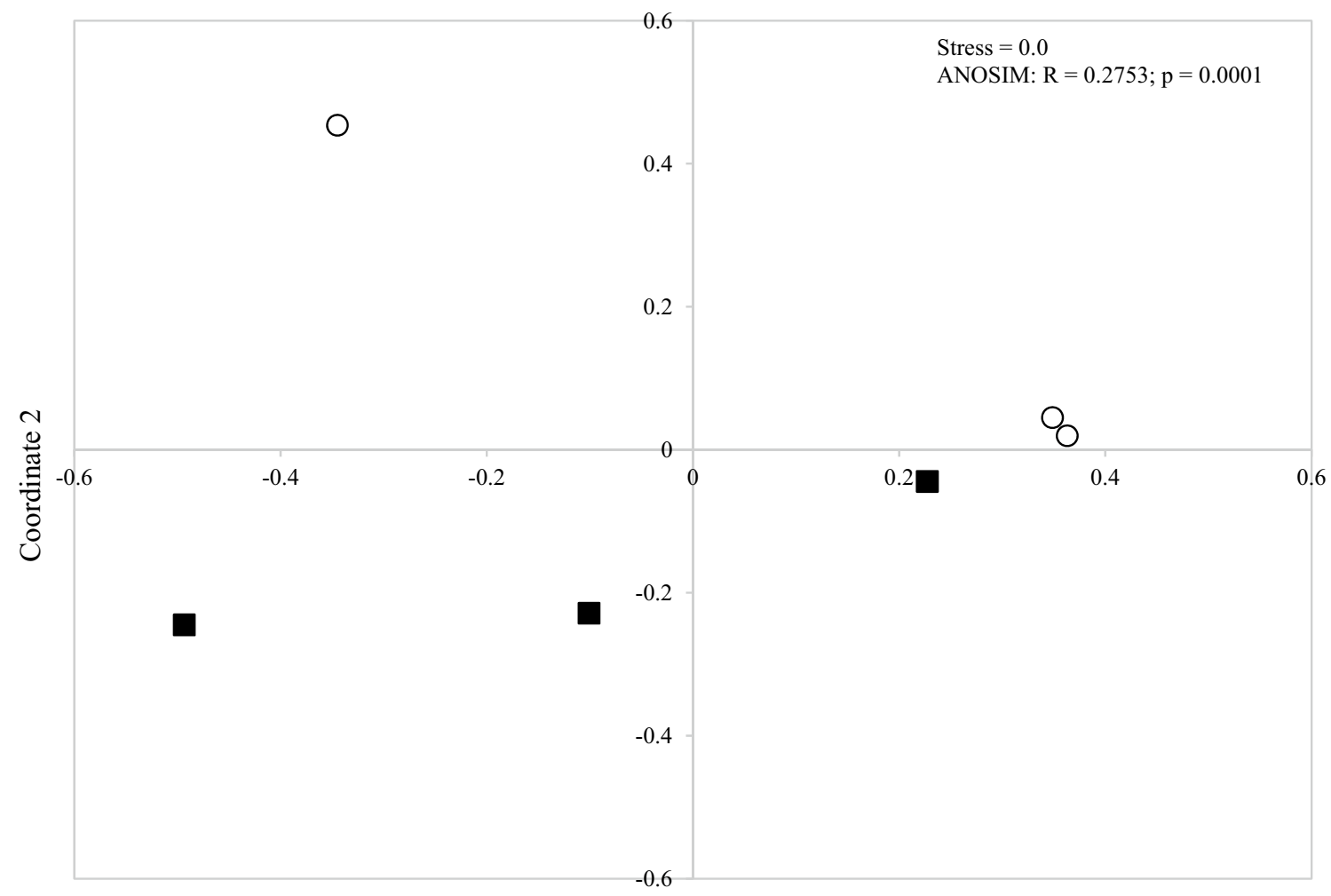

Coordinate 1

Fig. 3 Non-metric multidimensional scaling plot for ECM fungi communities on 1-year-old Abies alba seedlings based on Bray-Curtis distance across sites (black squares mean fir stands; open circles mean larch forecrops). Each point represents ECM assemblages of 30 seedlings

Fig. 4 Mean similarity dendrogram for the ECM fungi assemblages in study sites

\section{Similarity}

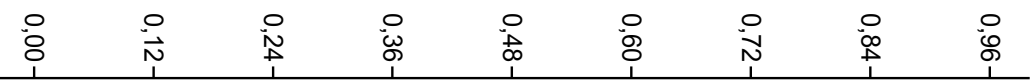


seedlings from the same locality, these authors (Comandini et al. 1998) identified $25 \mathrm{ECM}$ morphotypes ( $\mathrm{SI}=30$ ). Based on anatomical and morphological features, Kowalski (2008) found 35 ECM types on silver-fir seedlings in the Karkonosze National Park (Poland). Based on ECM sporocarp identification, Laganà et al. $(1999,2002)$ observed over 40 ECM fungal species in silver-fir forests in Tuscany (Italy). However assemblages of ECM fungal symbionts based on aboveground sporocarp identification can be significantly different from belowground ECM communities (data not published). ECM symbionts of $A$. alba are still poorly examined with utilization of molecular approaches. Based on DNA sequencing, sampled directly from ECM root tips, in German forests Cremer et al. (2009) and Schirkonyer et al. (2013) identified 33 and 15 taxa $(\mathrm{SI}=42)$ of $A$. alba symbionts, respectively, and Rudawska et al. (2015) observed 35 mycorrhizal fungal taxa $(\mathrm{SI}=64)$ on mature $A$. alba outside its natural range in Pomerania (northern Poland). In closely related to silver-fir Abies lasiocarpa, Kranabetter et al. (2009) identified 74 ECM symbionts $(\mathrm{SI}=95)$. Matsuda and Hijii (1999, 2004) revealed 37 morphotypes from Abies firma seedlings $(\mathrm{SI}=142)$.

The relative abundance of fir symbionts documented in fir stands in our previous study and presented here was comparable, the relative abundance of fir symbionts documented in pine (Ważny 2014), and larch forecrops was completely different. Fir seedlings from the pine forecrops formed mycorrhizas mostly with Clavulina cristata, Tomentella sp., Tuber puberulum and Clavulina sp. However, fir seedlings regenerating under larch canopy formed ectomycorrhizas mostly with unidentified fungus $1, T$. sublilacina, Tylospora sp., H. bailii, and T. asterophora. Only 6 of 48 fungal symbionts were common to pine and larch forecrops, including: Clavulina sp., Sebacina sp., Tomentella stuposa, Tomentellopsis sp., T. asterophora, and Xerocomus badius (Ważny 2014). Among 25 symbionts of fir seedlings regenerating in larch forecrops, 8 species were documented as symbionts of larch seedlings naturally regenerated under larch canopy documented by Leski and Rudawska (2012): Boletus pruinatus, Cenococcum geophilum, Hydnotrya tulasnei, Russula ochroleuca, R. puellaris, Thelephora terrestris, T. sublilacina, and X. badius.

The most frequent fungal taxa was unidentified fungus 1 (five sites), followed by B. pruinatus, $C$. geophilum and T. asterophora which were presented at least in four sites. Unidentified fungus 1 characterized brown mycorrhizas with the Hartig net and without a mantle. The Hartig net can appear before the fungal mantle (Nylund and Unestam 1982). Molecular analysis revealed that this morphotype was formed by various taxa and this is probably an initially stage of mycorrhiza of many fungal species which differentiates later on. On 2-year-old A. alba seedlings, this morphotype was observed; however, was not as frequent (data not published). Boletus pruinatus was previously documented as fungal component of ECM on silver-fir (Cremer et al. 2009; Schirkonyer et al. (2013); Ważny 2014) and European larch symbiont (Leski and Rudawska 2012), but it was not revealed as a dominant species. On the other hand, C. geophilum is a common, dominating fungal component of the ectomycorrhizas of many tree species (Aučina et al. 2011; Teste et al. 2009), silver-fir including (Cremer et al. 2009; Ważny 2014). Even though the investigation was conducted in A. alba natural range, we did not observe $L$. salmonicolor, known to be specific to $A$. alba, which has been already documented in the Carpathians (Ważny 2014), the Apennines (Comandini et al. 1998, 2001), and Tuscany (Laganà et al. 2002).

This is the first report concerning ECM of A. alba seedlings regenerating in larch forecrops using molecular approaches. These results shed a new light on the diversity of ECM fungal species associated with silver-fir. The diversity of ECM communities of 1-year-old silverfir seedlings regenerating in mature silver-fir stands was significantly higher than in neighboring larch forecrops. However, we still do not know, why the diversity ECM of silver-fir seedlings regenerating under larch canopy was different than in mature fir stands. The comparison ECM communities on mature fir and larch trees in the examined forests would provide the necessary insight to solve this problem.

Author contribution statement RW: laboratory works, data analysis, preparing the manuscript; SK: experimental design, collaboration in data analysis.

Acknowledgements The authors would like to thank anonymous reviewers for providing helpful comments on drafts of this manuscript. The research was supported by the University of Agriculture in Krakow (Department of Forest Pathology), Project BZ 573/KFL (2008-2011).

\section{Compliance with ethical standard}

Conflict of interest The authors declare that they have no conflict of interest.

Open Access This article is distributed under the terms of the Creative Commons Attribution 4.0 International License (http:// creativecommons.org/licenses/by/4.0/), which permits unrestricted use, distribution, and reproduction in any medium, provided you give appropriate credit to the original author(s) and the source, provide a link to the Creative Commons license, and indicate if changes were made. 


\section{References}

Abarenkov K, Nilsson RH, Larsson KH, Alexander IJ, Eberhardt U, Erland S, Høiland K, Kjøller R, Larsson E, Pennanen T, Sen R, Taylor AFS, Tedersoo L, Ursing BM, Vrålstad T, Liimatainen K, Peintner U, Kõljalg U (2010) The UNITE database for molecular identification of fungi-recent updates and future perspectives. New Phytol 186(2):281-285

Agerer R (1987-2007) Colour atlas of ectomycorrhizae. Einhorn-Verlag Eduard Dietenberger, Schwäbisch Gmünd

Aučina A, Rudawska M, Leski T, Ryliškis D, Pietras M, Riepšas E (2011) Ectomycorrhizal fungal communities on seedlings and conspecific trees of Pinus mugo grown on coastal dunes of the Curonian Spit in Lithuania. Mycorrhiza 21:237-245

Berndt R, Kottke I, Oberwinkler F (1990) Ascomycete mycorrhizas from pot-grown silver-fir seedlings (Abies alba Mill.). New Phytol 115:471-482

Bormann BT (1983) Ecological implications of photochromadiated seed germination in red alder. Forest. Science 29:734-738

Bray JR, Curtis JT (1957) An ordination of the upland forest communities of southern Wisconsin. Ecol Monogr 27:325-349

Colwell RK (2006) EstimateS: statistical estimation of species richness and shared species from samples. Ver8. Persistent. http:// purl.oclc.org/estimates

Comandini O, Pacioni G, Rinaldi AC (1998) Fungi in ectomycorrhizal associations of silver fir (Abies alba Miller) in Central Italy. Mycorrhiza 7:323-328

Comandini O, Pacioni G, Rinaldi AC (2001) An assessment of belowground ectomycorrhizal diversity of Abies alba Miller in central Italy. Plant Bios 135(3):337-350

Cremer E, Donges K, Liepelt S, Rexer K-H, Vendramin GG, Leyer I, Kost G, Ziegenhagen B (2009) Ontogenetic and genotypic effects of silver fir (Abies alba Mill.) on associated ectomycorrhizal communities. In: Cremer E (ed) Population genetics of silver fir (Abies alba Mill.) in the Northern Black Forest-preconditions for the recolonization of windthrow areas and associated ectomycorrhizal communities. http://archiv.ub.uni-marburg.de/ diss/z2009/0130/

De Román M, Claveria V, De Miguel AM (2005) A revision of the descriptions of ectomycorrhizas published since 1961. Mycol Res 109(10):1063-1104

Dobrowolska D (2008) Growth and development of silver fir (Abies alba Mill.) regeneration and restoration of the species in the Karkonosze Mountains. J For Sci 54:398-408

Dominik T (1961) Badanie mikotrofizmu zespołów roślinnych w Parku Narodowym w Pieninach i na Skałce nad Łysą Polaną w Tatrach ze szczególnym uwzględnieniem mikotrofizmu sosny reliktowej. Prace IBL 208:31-58

Eberhardt U, Verbeken A, Rinaldi AC, Pacioni G, Comandini O (2000) Lactarius ectomycorrhizae on Abies alba: morphological description, molecular charakterization and taxonomic remarks. Mycologia 92(5):860-873

Farfał D (2008) Root system vitality of natural and artificial regeneration of silver fir in the Karkonosze National Park. In: Barzdajn W, Raj A (eds) silver fir in the Karkonosze National Park, KPN Jelenia Góra, pp 87-104 (in polish)

Gardes M, Bruns TD (1993) ITS primers with enhanced specificity for basidiomycetes - application to the identification of mycorrhizae and rusts. Mol Ecol 2:113-118

Hall TA (1999) BioEdit: a user-friendly biological sequence alignment editor and analysis program for Windows 95/98/NT. Nucl Acids Symp Ser 41:95-98

Hammer O, Harpener DAT, Ryan PD (2001) PAST: paleontological statistics software package for education and data analysis. Paleontol Electron 4(1):9
Ishida TA, Nara K, Hogets T (2007) Host effects on ectomycorrhizal fungal communities: insight from eight host species in mixed conifer-broadleaf forests. New Phytol 174(2):430-440

Jaworski A (2011) Hodowla lasu, t. III. Charakterystyka hodowlana drzew i krzewów leśnych. PWRiL W-wa, s. 154-203 (in polish)

Kowalski S (1982) Role of mycorrhiza and soil fungi community in natural regeneration of fir (Abies alba Mill.) in Polish Carpathians and Sudetes. Eur J For Pathol 12(2):107-112

Kowalski S (2008) Mycorrhizae of the European silver fir (Abies alba Mill.) seedlings from natural and artificial regeneration in forests of the Karkonosze National Park. In: Barzdajn W, Raj A (eds) silver fir in the Karkonosze National Park. KPN Jelenia Góra, pp 175-212 (in polish)

Kowalski S, Obłoza E, Kwiatkowski G (1996) A study on a mycotrophy of the European fir (Abies alba Mill.) in different forest communities in selected mountain forest stands. Zesz Nauk AR w Krakowie, nr 308, Leśnictwo 25:23-37 (in polish)

Kranabetter JM, Durall DM, MacKenzie WH (2009) Diversity and species distribution of ectomycorrhizal fungi along productivity gradients of southern boreal forest. Mycorrhiza 19:99-111

Laganà A, Loppi S, De Dominicis V (1999) Relationship between environmental factors and the proportions of fungal trophic groups in forest ecosystems of the central Mediterranean area. For Ecol Manag 124:145-151

Laganà A, Agnolini C, Loppi S, Salerni E, Perini C, Barluzzi C, De Dominicis V (2002) Periodicity, fluctuations of macrofungi in fir forests (Abies alba Mill.) in Tuscany, Italy. For Ecol Manag 169:187-202

Lanfranco L, Perotto S, Longato S, Mello A, Cometti V, Bonfante P (1998) Molecular approaches to investigate biodiversity in mycorrhizal fungi. In: Varma A (ed) Mycorrhiza manual. Springer, Berlin, pp 353-372

Leski T, Rudawska M (2012) Ectomycorrhizal fungal community of naturally regenerated European larch (Larix decidua) seedlings. Symbiosis 56:45-53

Marx DH (1969) The influence of ectotrophic mycorrhizal fungi on the resistance of pine roots to pathogenic infections. I. Antagonism of mycorrhizal fungi to root pathogenic fungi and soil bacteria. Phytopathology 59:153-163

Matsuda Y, Hijii N (1999) Ectomycorrhizal morphotypes of naturally grown Abies firma seedlings. Mycoscience 40:217-226

Matsuda Y, Hijii N (2004) Ectomycorrhizal fungal communities in an Abies firma forest, with special reference to ectomycorrhizal associations between seedlings and mature trees. Can J Bot $82: 822-829$

Nara K (2008) Community developmental patterns and ecological functions of ectomycorrhizal fungi: implications from primary succession. In: Varma A (ed) Mycorrhiza. Springer, Berlin, pp 581-599

Nara K, Hogetsu T (2004) Ectomycorrhizal fungi on established shrubs facilitate subsequent seedling establishment of successional plant species. Ecology 85:1700-1707

Nylund JE, Unestam T (1982) Structure and physiology of ectomycorrhizae. I. The process of mycorrhiza formation in Norway spruce in vitro. New Phytol 91:63-79

Ostrowska A, Gawliński S, Szczubiałka Z (1991) Metody analizy i oceny właściwości gleb i roślin. Warszawa

Pachlewski R (1955) Badania mikotrofizmu jodły pospolitej (Abies alba Mill.) w naturalnych zespołach Gór Świętokrzyskich. Roczn Nauk Leśn 139:111-129

Perry DA, Amaranthus MP, Borchers JG, Borchers SL, Brained RE (1989) Bootstraping in ecosystems. Bioscieence 39:230-237

Robakowski P, Wyka T, Samardakiewicz S, Kierzkowski D (2004) Growth, photosynthesis, and needle structure of silver fir (Abies alba Mill.) seedlings under different canopies. For Ecol Manag 201:211-227. doi:10.1016/j.foreco.2004.06.029 
Rudawska M, Pietras M, Smutek I, Strzeliński P, Leski T (2015) Ectomycorrhizal fungal assemblages of Abies alba Mill. outside its native range in Poland. Mycorrhiza. doi:10.1007/ s00572-015-0646-3

Schirkonyer U, Bauer C, Rothe GM (2013) Ectomycorrhizal diversity at five different tree species in forests of the Taunus Mountains in Central Germany. Open. J Ecol 03:66-81. doi:10.4236/ oje.2013.31009

StatSoft, Inc (2011) STATISTICA (data analysis software system), version 10.0. http://www.statsoft.com

Stępniewska H, Rębisz P (2004) Mycorrhizae of fir (Abies alba Mill.) seedlings growing on sawdust-peat substrates of different periods of utilization. Sylwan 8:34-42 (in polish)

Teste FP, Simard SW, Durall DM (2009) Role of mycorrhizal networks and tree proximity in ectomycorrhizal colonization of planted seedlings. Fungal Ecol 2:21-30
Trappe JM (1962) Fungus associates of ectotrophic mycorrhizae. Bot Rev 28:538-606

Ważny R (2011) Mycorrhizas of Abies alba Mill. natural regeneration from forest stands in Experimental Forestry Unit in Krynica. Episteme 12(II):89-96 (in polish)

Ważny R (2014) Ectomycorrhizal communities associated with silver fir seedlings (Abies alba Mill.) differ largely in mature silver fir stands and in Scots pine forecrops. Ann For Sci 71:801-810. doi:10.1007/s13595-014-0378-0

White TJ, Bruns T, Lee S, Taylor J (1990) Amplification and direct sequencing of fungal ribosomal RNA genes for phylogenetics. In: Innis MA, Gelfand DH, Sninsky JJ, White TJ (eds) PCR protocols: a guide to methods and applications. Academic Press, London 315-322 